\title{
Coarsening upward sequences - the products of laterally established river subsystems, M. Devonian, Hornelen Basin, Norway
}

\author{
HENRIK OLSEN
}

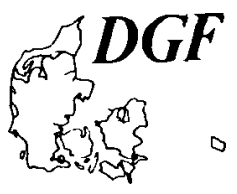

\begin{abstract}
Olsen, H.: Coarsening upward sequences - the products of laterally established river subsystems, $M$. Devonian, Hornelen Basin, Norway. Bull. geol. Soc. Denmark, Vol. 36, pp 203-219, Copenhagen, December, 31st, 1987. https://doi.org/10.37570/bgsd-1988-36-03

Investigations of sedimentary sequences in a marginal part of Hornelen Basin (M. Devonian, W Norway) have resulted in the interpretation of gradually established fluvial and fluviodeltaic subsystems adjacent to a major river system. A succession of 8 coarsening upward (CU) sequences (4.5-19 m thick) wad studied. Three sequence types are recognized: sequence type $\mathrm{A}, \mathrm{B}$ and $\mathrm{C}$. The lower part of all sequence types is composed of silty lacustrine flood basin deposits. The upper part of all sequence types is composed of sandy low sinuosity fluvial channel deposits. The middle part of the three sequence types is composed of sandy sheet splay deposits(sequence type A), crevassesplay deposits (sequence type B) and deltaic mouth bar deposits (sequence type $\mathrm{C}$ ). The genesis og the different types of $\mathrm{CU}$ sequences is explained by repeated lateral establishments of fluvial and fluvio-deltaic subsystems adjacent to a major humid fan-like river system. The establishment of the subsystems occurred in four phases: I) Initial fine-grained overbank flows into flood badin lakes. II) Sheet splay flows and/or crevasse splay flows. III) Establishment of distributary channels and associated deltaic mouth bars. IV) Progradation of channel/mouth bar couplets and filling up of the flood basin lakes.
\end{abstract}

Henrik Olsen, Institute of General Geology, University of Copenhagen, Øster Voldgade 10, DK-1350 Copenhagen K, Denmark. Present address: The Geological Survey of Greenland, Øster Voldgade 10, DK-1350 Copenhagen K, Denmark. February 11th, 1986.

\section{Setting}

The M. Devonian (Old Red Sandstone) Hornelen basin (fig. 1) is exclusively filled with continental sediments, mainly conglomerates, sandstones and siltstones (e.g. Steel 1976). The basin is notable for the pronounced sequential organization of its sedimentary fill, mainly controlled by tectonism (Steel 1976, Steel, Mæhle, Nilsen, Røe \& Spinnangr 1977, Bryhni 1978, Steel \& Gloppen 1980, Olsen 1985). The basin was flanked by conglomeratic alluvial fans dispersing sediments across the northern and southern fault margins (Steel et al. 1977, Bryhni 1978, Larsen \& Steel 1978, Steel \& Gloppen 1980, Gloppen \& Steel 1981). The dominant fill, however, came from an axial river system (Bryhni 1964a, b, 1975, 1978, Steel et al. 1977, Steel \& Aasheim 1978). This major river system dispersed sediments mainly towards the west through gravelly braided (proximal) and sandy low sinuosity (dis- tal) streams (Steel \& Aasheim 1978). The rapid decrease in grain size westwards, the inferred lobate shape of the axial sediment-bodies, the prominent prograding tendency to which the axial river system was subject and the occurrence of lacustrine deposits in distal and lateral-distal parts of the system, caused Steel and Aasheim (1978) to apply the term lacustrine fan delta to the axial river system. Lacustrine conditions were, however, only occasionally and locally occurring and humid fans like those described by Boothroyd and Ashley (1975) and Boothroyd and Nummedal (1978) are probably the closest modern analogues to the axial river system.

The northern marginal alluvial fans and the axial river system were usally separated by a flood basin tract dominated by lateral northwards directed flood deposition from the axial river system (Steel \& Aasheim 1978, Due 1983, 1984, Olsen 1984). Occasionally the flood basin was occupied by shallow lakes (Bryhni 1978, Pollard, 

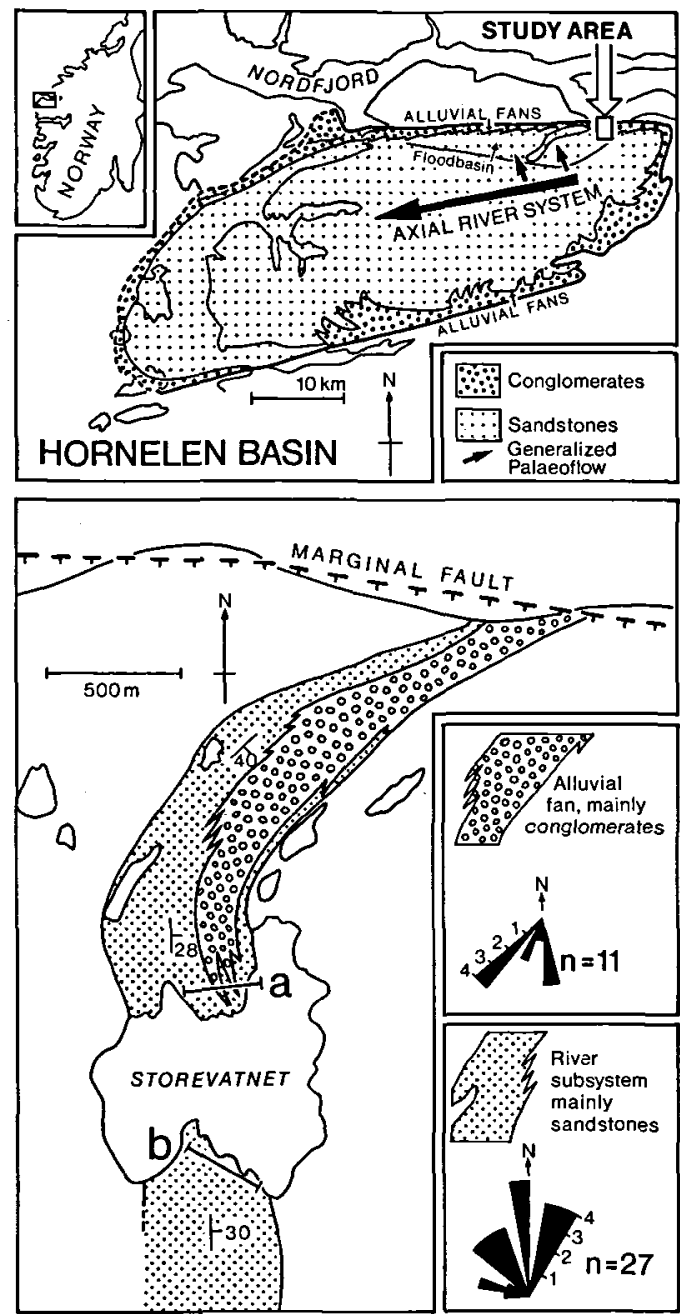

Fig. 1. Study area at the lake Storevatn close to the northern marginal fault of Hornelen Basin, W Norway. Palaeoccurrent roses for the river subsystem (large-scale trough cross-bedding from low sinuosity channel deposits) and the alluvial fan system (distal cross-bedded pebbly sandstones) are indicated. The sections shown in fig. 2 are indicated ( $a$ and $b$ ). The general map of the basin is based on Steel and Aasheim (1978).

Steel \& Undersrud 1982). Marginal alluvial fans dispersed conglomeratic material into the flood basin by means of debris flow and stream-flood deposition (Bryhni 1978, Larsen \& Steel 1978, Steel \& Gloppen 1980, Gloppen \& Steel 1981).

\section{Study area}

The excellent exposures around the lake Storevatnet (fig. 1) have been studied at several occa- sions. Bryhni (1978) made a detailed investigation of a succession of siltstones and very fine sandstones with concretionary calcite exposed along the east shore of Storevatnet. $\mathrm{He}$ interpreted these sediments as formed in temporary lakes between the alluvial fans in the north and the axial river system in the south, though he preferred to designate them as ponds rather than flood basin lakes. Later work by Pollard et al. (1982) in an overlying presumably mudstone and siltstone sequence exposed along the eastern shoreline concluded that these sediments were also of lacustrine origin. These sediments were correlated with coarsening upward deltaic sequences to the south. Thus according to Pollard et al. (1982) the axial river system prograded towards north into a lake situated in the Storevatnet area. Later work by Due $(1983,1984)$ in the supposed lacustrine deposits of Pollard et al. (1982) showed that these sediments are dominated by very fine sandstones with only millimetre-thick siltstone partings and they do not correlate with the deltaic sequences. The $\mathrm{c} .10 \mathrm{~cm}$ thisk sandstone beds are dominated by smallscale cross-bedding and horizontal lamination and the bed partings show frequent signs of emergence (desiccation cracks, adhesion warts, raindrop imprints). These sediments were accordingly interpreted as sheet flood deposits in agreement with interpretations of similar types of sediments along the northern basin margin (cf. Bryhni 1978). Palaeocurrents based on smallscale cross-bedding are towards north (Due 1984) though a minor westwards component is inferred from primary current lineation. The latter was also observed by Bryhni (1978) and this led him to the conclusion that the sheet flood deposits were deposited mainly by westward currents. The main sediment dispersal seems, though, to be directed towards north into the flood basin by means of overbank floods dispersed laterally away from the mainly westward flowing axial river system (Steel et al. 1977, Due 1984).

The succession of shallow lacustrine deposits and subaerial sheet flood deposits along the eastern shoreline of Storevatnet is underlain by a succession of eight coarsening upward sequences 4.5-19 $\mathrm{m}$ thick exposed along the northern and partly along the southern shorelines (figs $1 \& 2$ ). These sediments, which are also derived from the axial river system are underlain by a c. $100 \mathrm{~m}$ 


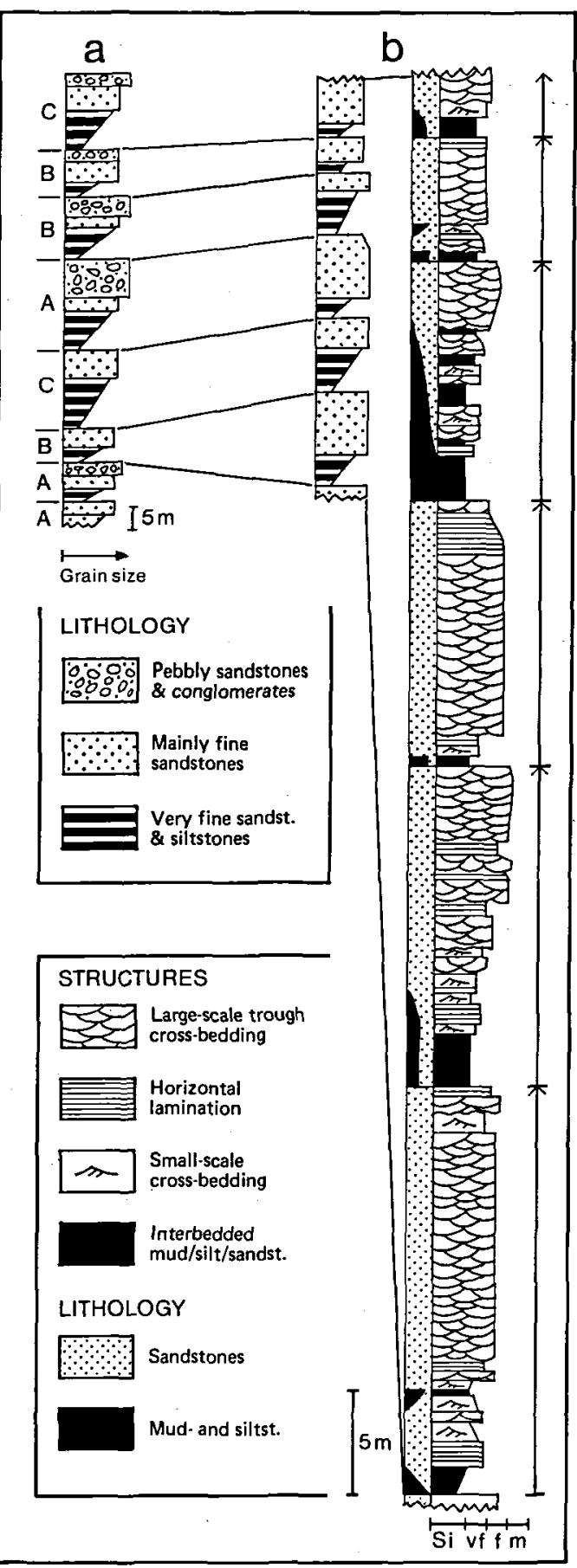

Fig. 2. Two vertical sections through the depositional sequences in the study area. Identification of the different sequence types is indicated $(\mathrm{A}, \mathrm{B}, \mathrm{C})$; no systematic trend is recognized. Section $b$ is shown in more detail. See fig, 1 for location of sections. thick very fine sandstone succession of mainly subaerial sheet flood origin (Olsen 1984).

The coarsening upward sequences, the subject of the present paper, grade up from interbedded mud, silt and very fine sandstones at the base to mainly fine trough cross-bedded sandstones in the upper part (fig. 2). Pebbly sandstones and conglomerates interbed with the fine-grained sandstones in the coarsening upward sequences exposed along the northern shoreline (fig. 2a). These pebbly sandstones and conglomerates are part of en alluvial fan body that thickens north of Storevatnet and indicate a southward sediment dispersal (fig. 1). Palaeocurrents from the coarsening upward sequences indicate a northward direction (fig. 1). By comparison with palaeocurrents measured by Bryhni (1978, his fig. 6) it is seen that a northward palaeoflow direction is persistent until $4 \mathrm{~km}$ south of Storevatnet where a sharp change to a westward direction is observed. It is therefore apparent that the northward transport direction in the study area does not reflect a progradation of the entire axial river system towards north. The break in palaeocurrent direction could rather be explained by a development of a northward directed subsystem connected to the mainly westward flowing axial river system. The stacking of coarsening upward sequences in the study area accordingly reflects repeated gradual establisments and rapid abandonments of river subsystems prograding northwards into the flood basin tract.

The coarsening upward sequences formed by these river sybsytems are described in detail in the following. Three sequence types are recognized, types $A, B$ and $C$. Each sequence type is subdivided into 3 or 4 divisions.

\section{Sequence type A}

Three divisions are recognized in sequence type A (fig. 4), from base to top division AI, AII and AIII.

\section{AI, BI; CI - Lacustrine deposits}

The lower division of all sequence types is composed of the same facies association. The following description is therefore valid for division AI, $\mathrm{BI}$ and $\mathrm{CI}$. The lower division is composed of a 


\section{FACIES TYPES}

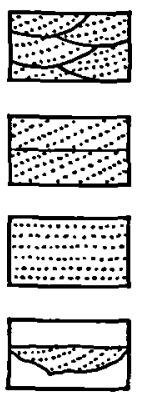

Large-scale trough cross-bedded sandstones

Large-scale planar cross-bedded sandstones

Horizontally laminated sandstones

\section{Scour-and-fill structures}

$\lll \ll$

Small-scale unidirectional cross-bedded sandstones

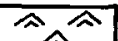

Small-scale bidirectional cross-bedded sandstones

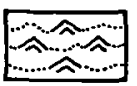

Undulating laminated sand-and siltstones

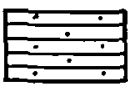

Thinly interbedded sand- and siltstones

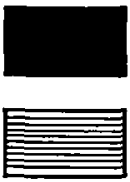

Massive siltstones

Horizontally laminated mud- and siltstones

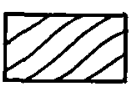

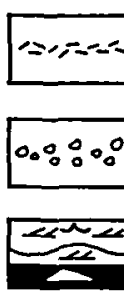

Intraformational clasts

Extraformational clasts

Flaser, wavy, lenticular bedding

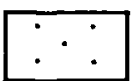

Massive sandstones

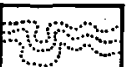

Penecontemp. deformation

\section{LITHOLOGY}

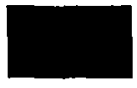

Mud-and siltstones

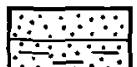
Sandstones Silty sandstones Heterolith

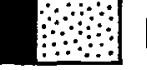
$\because \because 00$ Granules-pebbles

\section{DIRECTIONAL FEATURES}

\section{$\Uparrow \quad$ Large-scale cross-bedding \\ $\& \begin{aligned} & \text { Small-scale bidirectional } \\ & \text { cross-bedding }\end{aligned}$}

Fig. 3. Legend for figs 4, 10, and 11 .

horizontally laminated mud- and siltstone facies and a thinly interbedded very fine sand- and siltstone facies ranging from $0.3-1.6 \mathrm{~m}$ thick. Usually one of the facies dominates.

The horizontally laminated mud- and siltstone facies consists of horizontal, laterally continuous 1-10 $\mathrm{mm}$ thick layers of mudstone, siltstone, sandy siltstone and occasionally silty sandstone (fig. 5). Individual layers may be nongraded, but normal grading is frequently observed. The grading is typically from fine/medium silt $(4-16 \mu)$ to

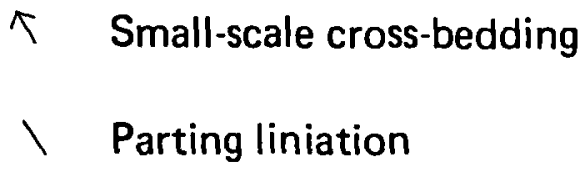

mud $(1-6 \mu)$. Local erosional contacts of layers are often observed. Desiccation cracks and other signs of emergence are absent.

The thinly interbedded sand- and siltstone facies is composed of horizontally interbedded very fine sandstones and siltstones (fig. 6). The sandstone beds range from $<0.5 \mathrm{~cm}$ to $2.5 \mathrm{~cm}$ in thickness, whereas the siltstone beds never exceed $1.5 \mathrm{~cm}$. Both sandstone and siltstone beds appear massive in the field, but $\mathrm{x}$-ray photographs of thin rock slabs indicate a well devel- 
a

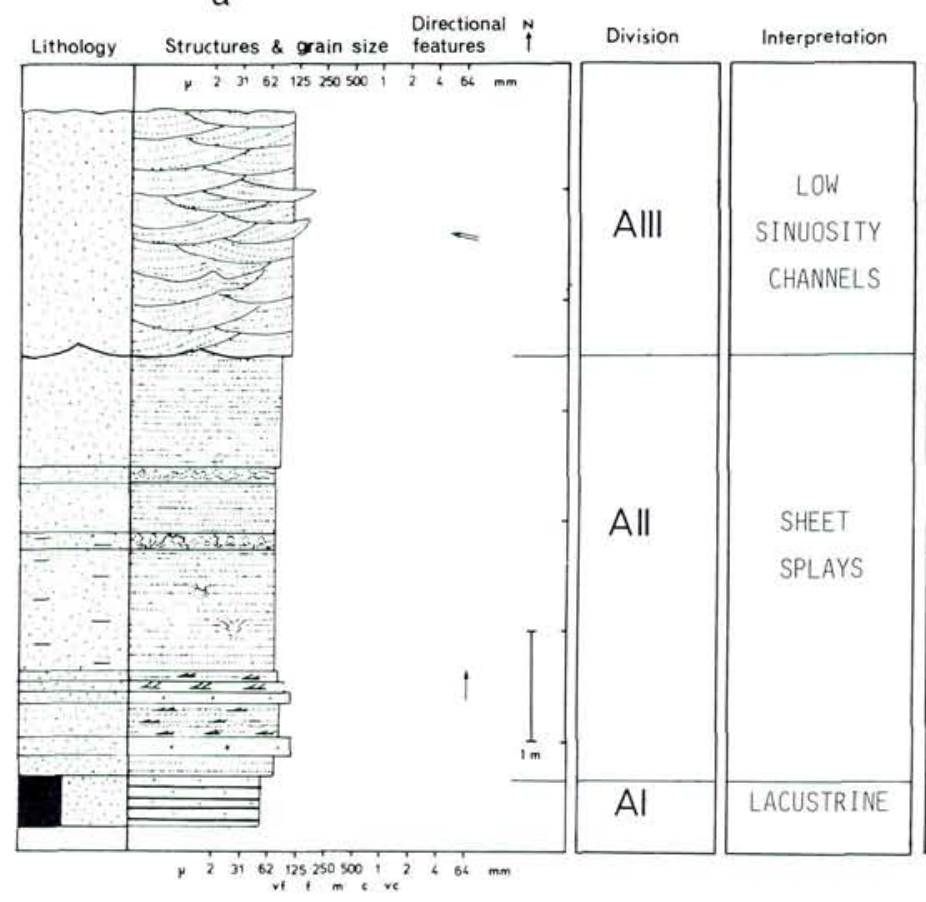

b

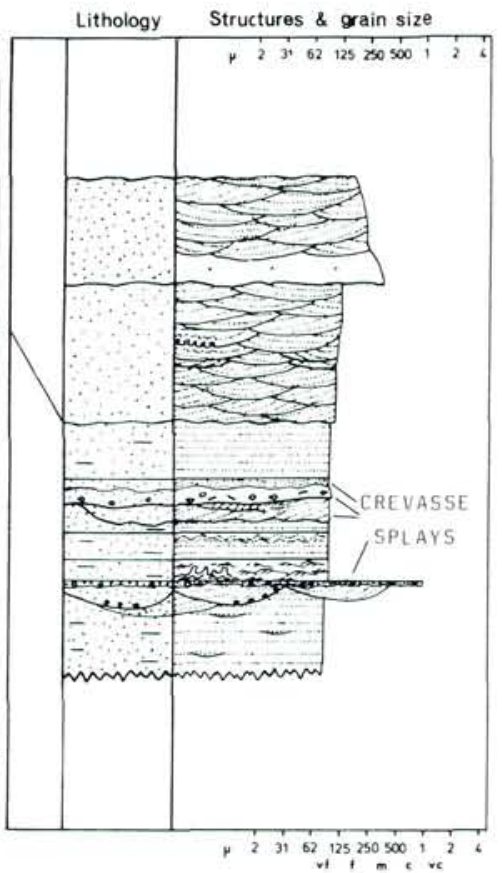

Fig. 4. Sequence type A. This sequence type reflects deposition of fine-grained material during initial overbank flooding into a flood basin lake followed by sheet splay deposition (and crevasse splay). Finally a system of perennial fluvial channels is formed.

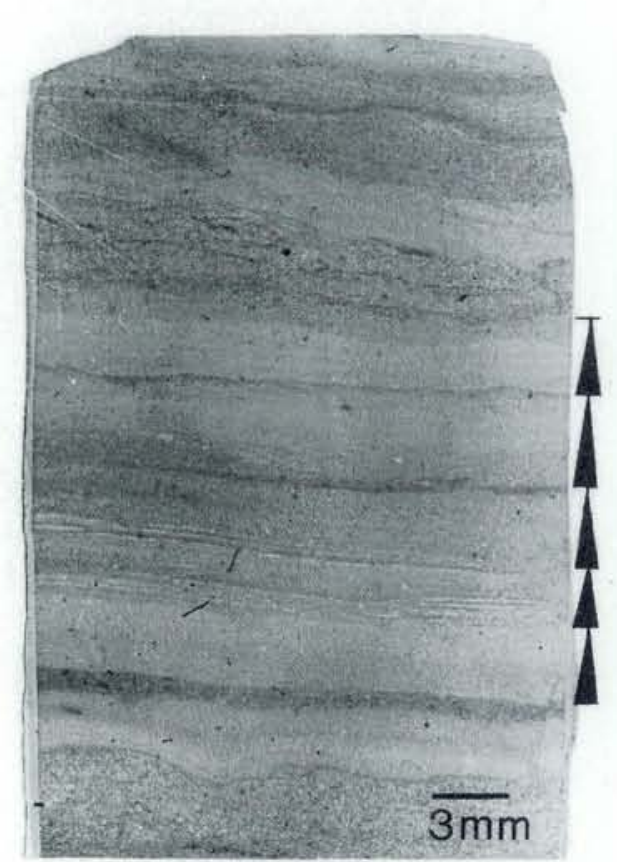

Fig. 5. Thin section of the horizontally laminated mud- and siltstone facies, showing normal graded layers. This facies is interpreted as lacustrine density underflow deposits. oped horizontal lamination in the siltstone beds. The sandstone beds, on the other hand, exhibit only a faint subhorizontal lamination or no lamination at all. The lower contacts of the sandstone beds are very often erosive, whereas the lower contacts of siltstone beds are always non-erosive. Desiccation cracks and other signs of emergence are absent.

Interpretation: The lateral continuity (exceeding the width of outcrops), normal grading and frequent erosional contracts of individual layers in the horizontally laminated mud- and siltstone facies suggest deposition from density underflows, flowing into a body of standing water. Similar deposits have been reported from modern lakes (Lambert \& Hsü 1979) and from other parts of Hornelen Basin (Pollard et al. 1982) and have also been interpreted as density underflow deposits.

The thinly interbedded sand- and siltstone facies is interpreted as reflevting rapid deposition of sand followed by suspension fall-out of silt. The lack of well-developed lamination within the sandstone beds may indicate a density underflow origin rather than a traction mechanism. Accord- 


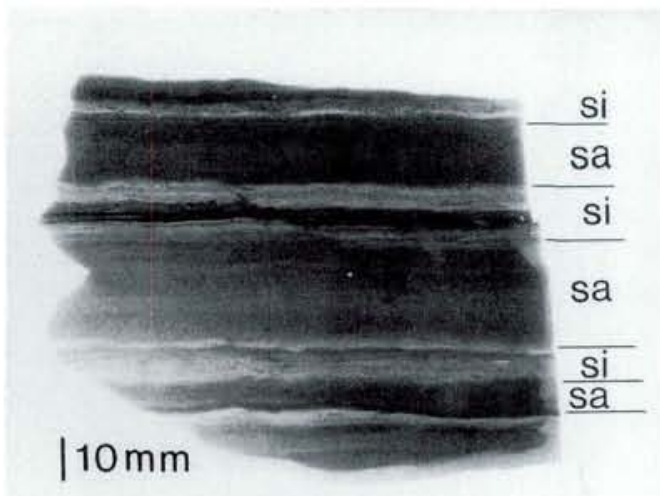

Fig. 6. Thinly horizontally interbedded very fine sandstone and siltstones, division AI. X-ray photograph. sa: sand, si: silt. Note the lack of well-developed stratification in sandstone beds. Irregularity of bedding is due to penecontemporaneous deformation. This facies is interpreted as density underflow (sa) and suspension fall-out (si) deposition.

ing to Middleton and Hampton (1976) rapid deposition from suspension in density flows (turbidity currents) prevents the formation of traction structures such as lamination, and "churning" by interfacial waves destroys whatever traces of lamination may have been formed.

The sediments of division $\mathrm{AI}, \mathrm{BI}$ and $\mathrm{CI}$ are accordingly interpreted in terms of lacustrine deposition dominated by density underflows. The absence of desiccation cracks and other signs of emergence also indicates subaqueous deposition.

\section{AII - Sheet splay deposits}

Division AII is dominated by horizontally laminated very fine sandstones with minor occurrences of small- scale cross-bedding (fig. 4). The horizontally laminated beds are sometimes associated with scour-and-fill structures. Occasionally up to $5 \mathrm{~cm}$ thick siltstone beds cap the sandstone beds. These beds sometimes exhibit desiccation cracks.

The horizontally laminated sandstone beds (fig. 7) are sheet-like, exhibiting either planar erosive or weakly scoured bases. Individual beds are usually $5-20 \mathrm{~cm}$ thick but may range up to $1 \mathrm{~m}$ in thickness. Although the beds seldom split along parting planes, a few parting planes exhibiting parting lineation were observed. Occasionally sandstone beds showing unidirectional small- scale cross-bedding throughout or rapid transitions (both laterally and vertically) from horizontal lamination to small-scale cross-bedding were observed.

The horizontally laminated and small-scale cross-bedded sheet-like sandstone beds are sometimes interbedded with scour-and-fill structures (fig. 4b). These structures are usually symmetrical to slightly asymmetrical trough forms less than $0.5 \mathrm{~m}$ deep and $1-2 \mathrm{~m}$ long. The scours show different types of fill, including large-scale crossbedded sand and intraformational conglomerates. The grain size is highly variable, ranging from silty very fine sand to pebbly mediumcoarse sand. Usually several lateral equivalent scour-and -fill structures form a horizon that probaly represents one event.

Interpretation: Individual sheet-like very fine sandstone beds are thought to represent individual depositional events. The horizontally laminated sandstone beds reflect deposition under conditions of high stream power, i.e. plane bed phase in upper flow regime, as indicated by the association with parting lineation (Harms 1975). Small-scale cross-bedded sandstone beds and beds showing rapid transitions from horizontal lamination to small-scale cross-bedding are indicative of lower flow powers, i.e. lower flow regime and transitional lower/upper flow regime respectively. Siltstone cappings represent suspension fall-out after cessation of bedload transport. The dominance of solely horizontally laminated sandstone beds with no systematic upward transitions to small-scale cross-bedding indicates rapid waning of flows with no low stage ripple formation. They may be ascribed to flowing out on dry sur-

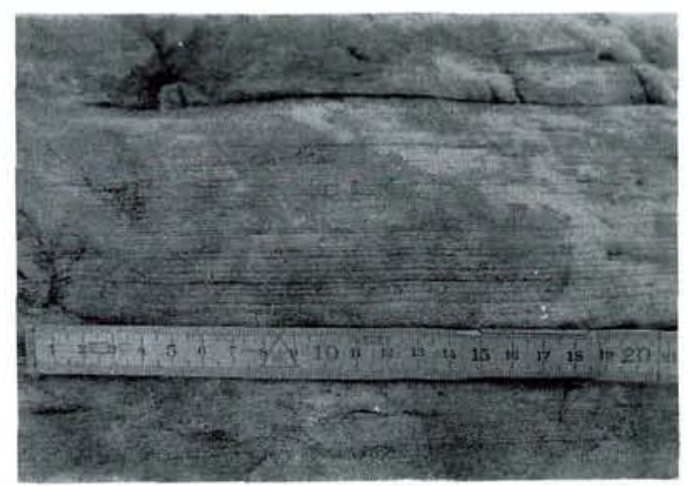

Fig. 7. Horizontally laminated very fine sandstone, division AII. Cm-rule shows scale. 
faces and percolation of water into the stream bed, resulting in rapid loss of carrying power. The occurrence of desiccation cracks in the siltstone beds supports the suggestion of a subaerial environment.

The dominance of horizontally laminated sandstone beds and the lateral extension of these beds without significant thickness variations suggest that division AII was deposited by sheet floods (e.g. Tunbridge 1981). The flow direction indicated by small-scale cross-bedding was towards north. This indicates flooding towards north laterally from the main westwards flowing axial river system. In Myklebustdalen c. $5 \mathrm{~km}$ west of the present study area a c. $1000 \mathrm{~m}$ thick succession of flood basin deposits has similarly been interpreted in terms of lateral flooding out from the main axial river system (Steel \& Aasheim 1978). A c. $100 \mathrm{~m}$ thick succession east of Storevatnet was interpreted in a similar manner by Due $(1983,1984)$. The overbank nature of the present sheet flood deposits justifies the term sheet splay deposits applied to the same type of deposits by Galloway (1981).

In a context of overbank flood deposition the scour-and-fill structures may be attributes to crevasse splaying. Coleman (1969) recorded a multichannel crevasse splay type from the overbank environment of the Brahmaputra River. Accord- ing to Coleman (1969) the sediment-laden splay water overrides the stream bed and scouring occurs only locally, subsequently followed by deposition in the scours. Scour-and -fill structures are the dominant depositional structures of this crevasse splay mechanism (Coleman 1969). The present scour-and-fill structures are interpreted in a similar manner.

\section{AIII, BIII, CIV - Low sinuosity channel} deposits

The upper division of sequence type $\mathrm{A}$, division AIII, shows a close resemblance to the upper division of all other sequence types. The differences noted are best explained as variations within a common depositional environment. The following description is thus based on the upper division of all three sequence types, i.e. divisions AIII, BIII and CIV (figs 4, 10, 11).

The upper division of the CU sequences (fig. 8) is dominated by cosets of $8-40 \mathrm{~cm}$ thick sets of large-scale trough cross-bedded very fine to coarse sandstones with a dominance of the fine sand fraction (fig. 9). The sorting is generally good, but concentrations of coarser sands, granules, pebbles and silt flakes along the lower part of foresets or littering the base of trough cross- b

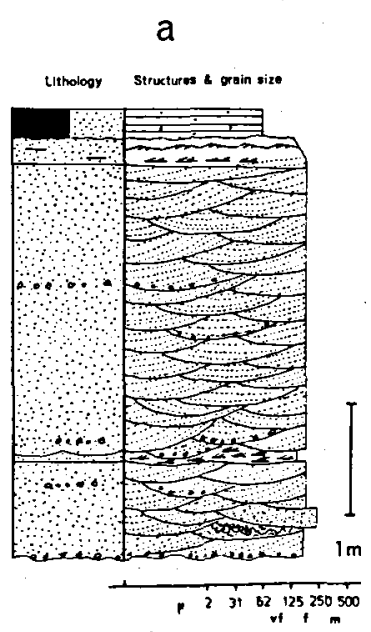

C

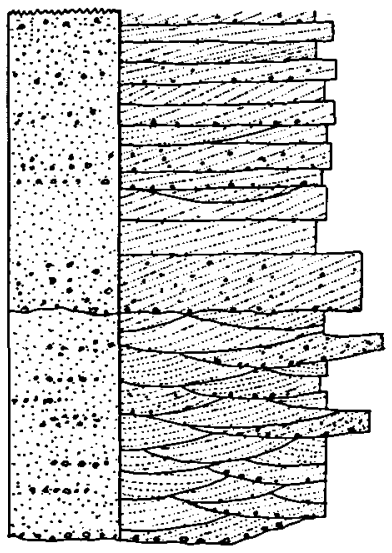

d

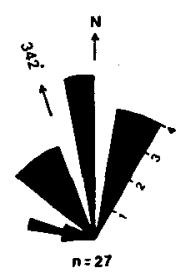

Fig. 8. Examples of upper divisions of coarsening upward sequences, interpreted as low sinuousity (perennial) fluvial channel deposits. $a$ is the most typical type of the upper divisions, dominated by trough cross-bedding. $b$ was laid down in shallow channels. $c$ is interpreted as a sandflat sequence. 
sets are common in this facies. Thin, often finer grained, intervals of small-scale unidirectional cross-bedding are sometimes seen interbedded with the large-scale trough cross-bedding (fig. 8a). Occasionally large-scale trough cross-bedding is interbedded with large-scale planar wedge-formed cross-bedding, small-scale crossbedding and horizontal lamination, showing rapid alternation of facies types both laterally and vertically and frequent truncations by scoured surfaces (fig. 8b). Two examples of cosets of large-scale planar cross-bedding were observed in the upper division of coarsening upward sequences. In both examples a thick $(>50 \mathrm{~cm})$ planar tabular cross-set is overlain by a coset of smaller ( $<30 \mathrm{~cm}$ thick) planar tabular and wedgeformed cross-sets and occasional trough crosssets (fig. 8c).
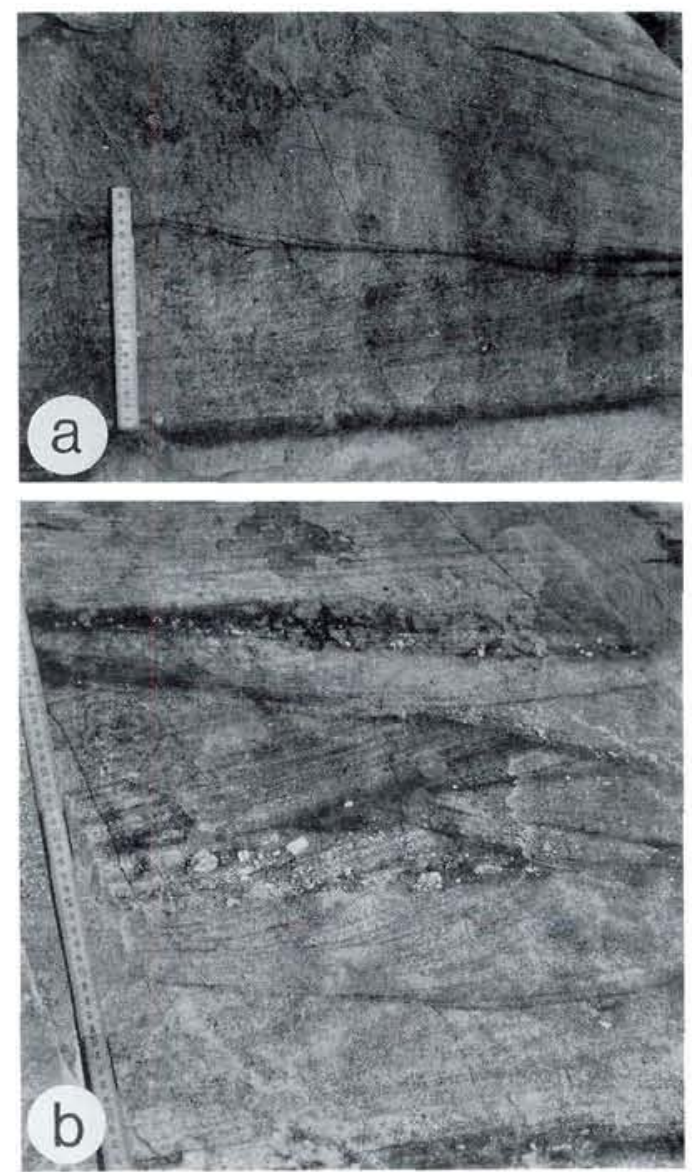

Fig. 9. Large-scale trough cross-bedding, $a$ : wellsorted fine sandstone sets, palaeoflow towards the viewer. $b$ : sets with concentrations of granules and small pebbles at base of sets, palaeoflow obliquely to the left towards the viewer. Scale in $\mathrm{cm}$.
The upper division is usually rather abruptly succeeded by the fine-grained lower division of the overlying coarsening upward sequence.

Palaeocurrents deduced from larce-scale trough cross-bedding (fig. 1) are unimodal, varying between $277^{\circ}$ to $29^{\circ}$ (mean $342^{\circ}$ ). The maximum azimuthal spread of palaeocurrent directions within individual upper divisions is $53^{\circ}$.

Interpretation: The association of large-scale trough and planar cross-bedding, small-scale cross-bedding and horizontal lamination, the unimodal palaeoflow with low variations within individual divisions, the paucity of grain sizes finer than very fine sand, the lack of well defined fining upward sequences and the lack of epsilon cross-bedding suggest a low sinuosity fluvial channel origin for the upper division af $\mathrm{CU}$ sequences (e.g. Harms \& Fahnestock 1965, Miall 1977).

Large-scale trough cross-bedding is formed by dune migration in the upper part of lower flow regime (e.g. Harms et al. 1982). Studies of modern low sinuosity sandy streams show that the main channels are dominated by migrating dunes so that in-channel deposition is characterized by large-scale trough cross-bedding whereas sand bars are internally characterized by planar tabular cross-bedding (Harms \& Fahnstock 1965, Miall 1977, Cant \& Walker 1978).

The dominance of trough cross-bedding and absence of tabular cross-bedding in the bulk of the measured upper divisisions indicate that deposition was dominated by in-channel deposition and the streams were consequently characterized by very low braiding tendences.

The thin intervals of small-scale cross-bedding (fig. 8a) are interpreted as low stage deposits by small current ripples.

The occasional occurrences of cosets of largescale planar cross-bedding, e.g. fig. $8 \mathrm{c}$, show obvious similarities to sandflat sequences described by Cant and Walker (1978) and are interpreted in the same manner.

Upper divisions characterized by numerous scoured surfaces and rapid alternation of facies types (fig. 8b) were probably formed in minor channels occupying topographically higher parts of the fluvial system because such channels are greatly affected by river stage, and flow tends to be intermittent (Miall 1977, Cant \& Walker 1978). Similar alternations of facies have also 
been interpreted as river stage controlled by Bryhni (1978) from other parts of the Hornelen Basin.

Summary - sequence type A

The subdivision of sequence type $\mathrm{A}$ into three divisions reflects the change from a lacustrine flood basin environment (division $\mathrm{AI}$ ) to a flood basin environment dominated by subaerial sheet splay flows (division AII) and ultimately a low sinousity fluvial channel environment (division AIII).

\section{Sequence type B}

Sequence type $B$ is subdivided into three divisions (fig. 10), from base to top division BI, BII and BIII. The lower division (BI) and upper division (BIII) have already been described under sequence type $A$.

\section{BII -Crevasse splay deposits}

The middel division of sequence type B (BII, fig. 10 ) is dominated by very fine to fine sandstones, although siltstones may occur as up to $1 \mathrm{~m}$ thick

a

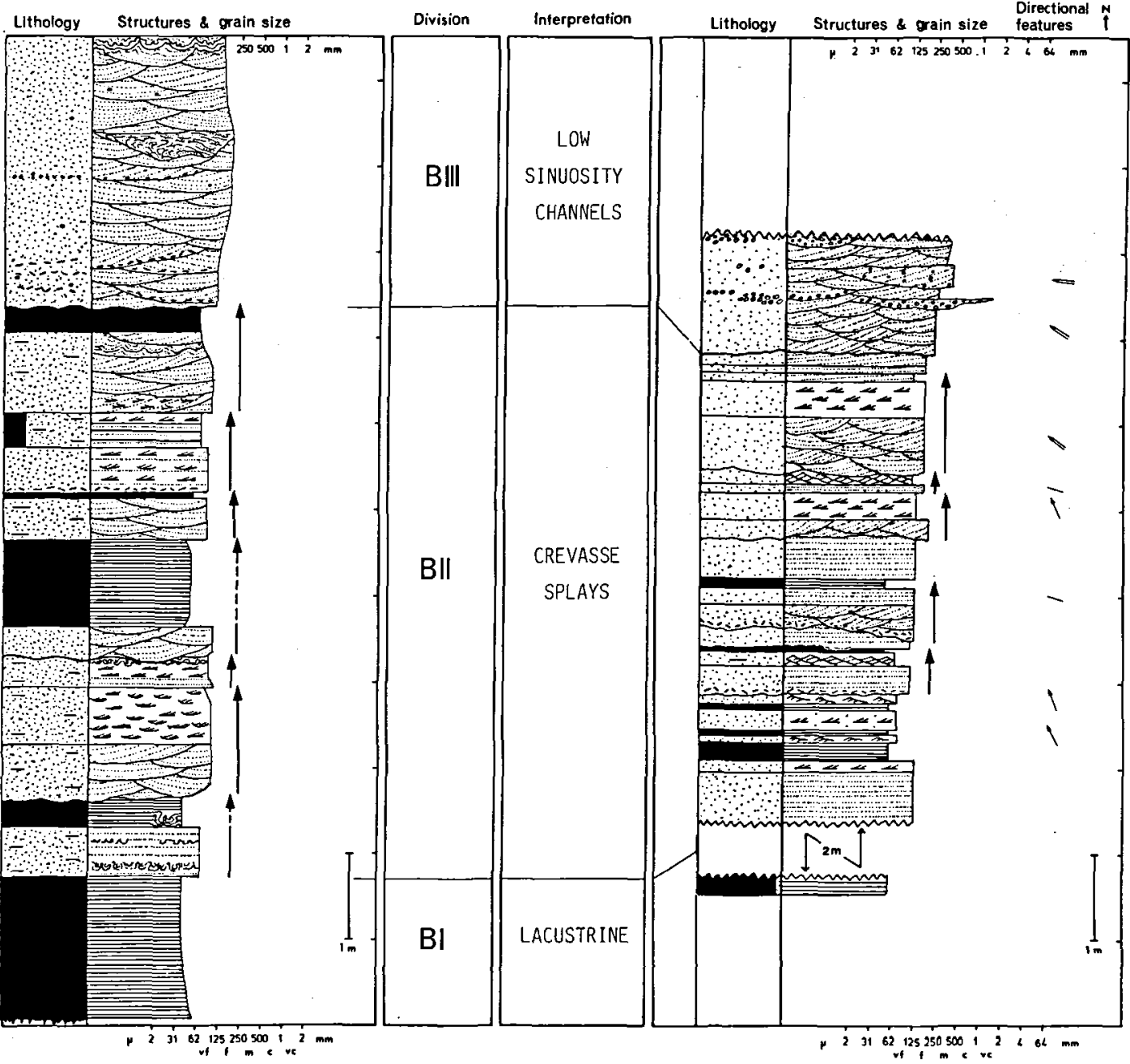

Fig. 10. Sequence type B. This sequence type indicates initial fine-grained lacustrine deposition followed by crevasse splay flows (small fining upward sequences are indicated). Finally a system of perennial low sinuosity fluvial channels formed. 
beds in the lower part of the division. The siltstones are frequently horizontally laminated, but the lamination is usally very faint. The sandstones show small-scale cross-bedding, largescale trough cross-bedding and horizontal lamination with parting lineation.

Division BII is characterized by numerous erosional surfaces, both planar and irregular. The erosional surfaces constitute the bases of smallscale (0.2-1.4 $\mathrm{m}$ thick) sequences. The lower part of these sequences is composed of very fine to fine sandstone showing horizontal lamination or large-scale trough cross-bedding, overlain either by very fine sandstone with small-scale cross-bedding or by siltstone. The small-scale sequences are marked with arrows in the graphic logs fig. 10. Some of the small-scale sequences are clearly channel-formed however this feature is generally difficult to perceive due to the orientation of most of the outcrops almost parallel to the palaeoflow.

Palaeocurrents in division BII are unimodal, northwards. The maximum spread of palaeocurrents within individual BII divisions is $56^{\circ}$.

Interpretation: The fining upward trend and change in stratification types within the smallscale sequences indicate deposition during decreasing flow intensity.

The association with thick lacustrine deposits (division BI) and absence of mouth bar deposits suggest intermittent sediment input into a lake. The small-scale sequences closely resemble in both scale, stratification trend and fining upward tendency crevasse splay sequences described by Elliott (1974) and Bridge (1984). The intermittent flow conditions could accordingly be associated with flood flow in crevasse splay channels.

The unimodal northwards palaeocurrents indicate crevassing out from an alluvial channel belt to the south, probably the westward flowing axial river system.

The lack of scour-and -fill structures typical for multi-channel crevasse splays (Coleman 1969) indicates a single-channel origin of the sequences. The planar erosive bases of some of the smallscale sequences reflect either sheet splay flows or distal unconfinement of the crevasse splay flows as described by Elliott (1974).

Desiccation cracks were rarely observed whereas wave-ripple bedding more frequently occurred, suggesting that the depositional surface was usually covered by lake water. The thicker siltstone beds indicate that during prolonged periods without crevasse splay flow the lakes received fine suspended silt, probably from minor overbank floods.

\section{Summary - sequence type B}

The subdivision of sequence type $B$ into three divisions reflects initial lacustrine deposition (division $\mathrm{BI}$ ) followed by crevasse splay deposition (division BII) and finally establishment of perennial low sinuosity channels.

Sequence type B differs in two ways from sequence type A: Firstly the splay deposits in sequence type $B$ are deposited mainly from crevasse splay flows and not from sheet splay flows. Secondly splay deposition recorded from sequence type $\mathrm{B}$ was mainly subaqueous, whereas splay deposition recorded from sequence type $A$ was subaerial.

\section{Sequence type C}

Sequence type $C$ is subdivided into 4 divisions division CI, CII, CIII and CIV (fig. 11). Division CI (lacustrine deposits) and division CIV (low sinuosity channel deposits) were described under sequence type $\mathrm{A}$.

\section{CII - Deltaic mouth bar deposits}

Division CII (fig. 11) is divided into a lower and an upper portion. The lower portion consists of undulating laminated, horizontally laminated and small-scale cross-bedded very fine sandstones and horizontally laminated and massive siltstones.

The undulating lamination (fig. 12a) is characterized by local pinching and swelling of individual laminae. The lamination frequently swings up to a low-angle cross-lamination $\left(<15^{\circ}\right)$ indicating a SSE-wards directed flow. Undulating lamination occurs mostly in moderately sorted very fine sand to coarse silt beds. Grain size segregation between individual laminae is generally rather poor.

The small-scale cross-bedding (fig. 12b) is characterized by a very low ripple symmetry index of formsets, about 1.5. The forest dips are 


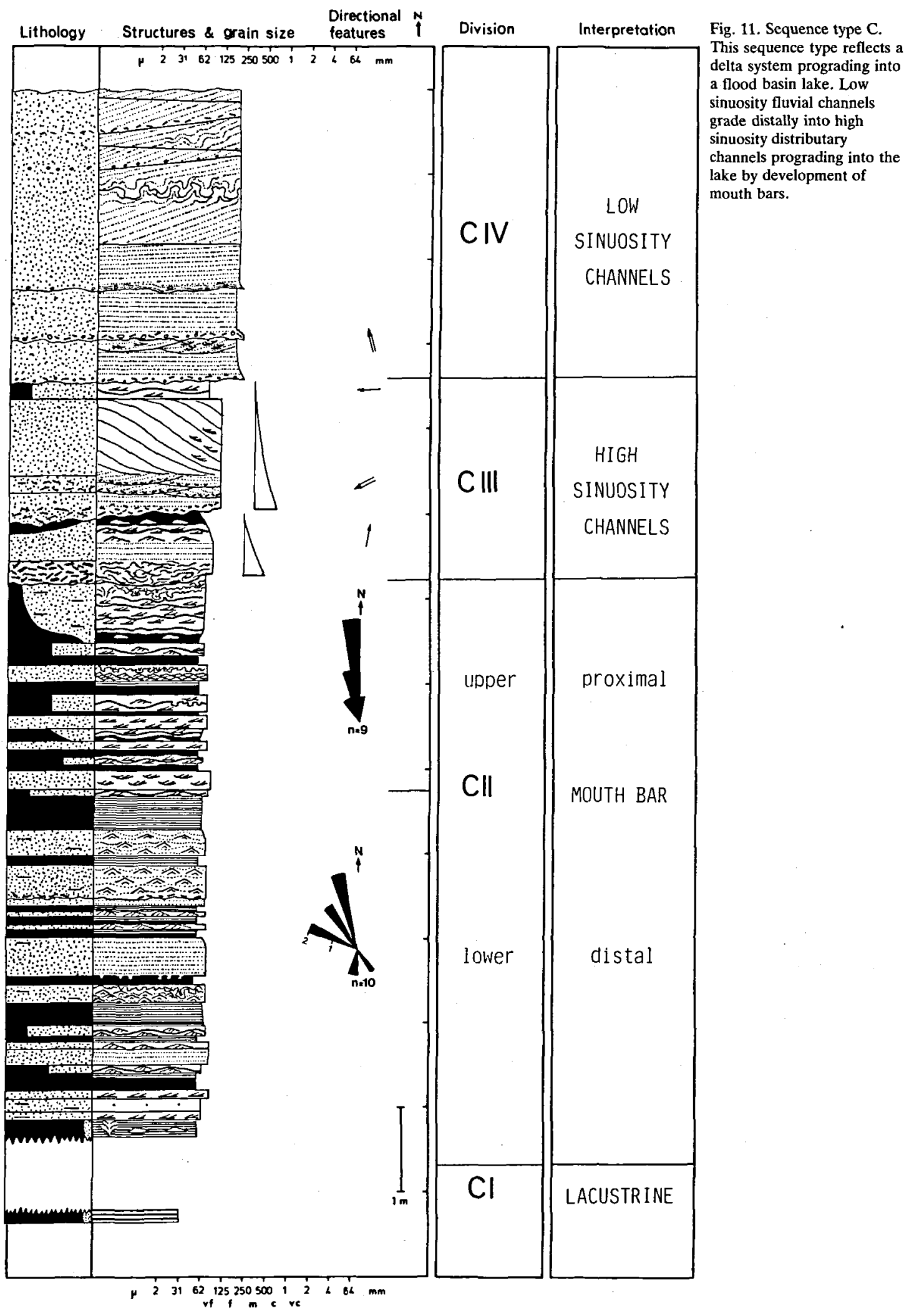


undirectional, northwestwards (form-concordant), but foreset off-shoots are occasionally observed.

Horizontally laminated siltstones and very fine sandstones are characterized by moderate sorting and low granulometric contrasts between individual alminae. Occasionally the lamination shows transitions to weak cross-lamination.

Interpretation: Undulating lamination has been described by de Raaf et al. (1977) and interpreted as the result of low energy wave agitation. The undulating lamination occasionally shows lateral and vertical transitions to small-scale cross-bedding, implying a close genetic relationship. The south-southwestwards dip of cross-laminae in the undulating lamination is however opposite to the dip of foresets of the small-scale cross-bedding. This observation may imply that an asymmetrical (net SEE) wave motion was responsible for the cross-laminae dip directions in the undulating lamination, whereas opposite northwestwards directed current action was sometines active at the same time resulting in transverse combined current/wave ripple bedding (cf. Reineck \& Singh 1980) with opposing foreset dips, only occasional off-shoots and low ripple symmetry index.

The horizontally laminated siltstones seem to be similar to the evenly laminated streaked muds of de Raaf et al. (1977). According to them, the low granulometric contrasts between laminae are due to suspension fall-out during weak wave oscillation which occasionally reached the bed, molding the even lamination into weak cross- lamination. The horizontally laminated very fine sandstones are interpreted in a similar manner.

The massive siltstones are interpreted as deposited by rapid suspension fall-out.

The upper portion of division $\mathrm{CII}$ is dominated by small-scale unidirectional (NNW) cross-bedded very fine sandstones and massive siltstones, exhibiting wavy and in some cases lenticular bedding. Ripple forms always possess clear asymmetrical profiles (RSI $>2.6)$ that conform to the internal cross-lamination. No foreset off-shoots were observed.

Interpretation: These features suggest a current origin for the small-scale cross-bedding in the upper portion. No signs of wave agitation were noticed.

The sedimentary facies association of division $\mathrm{CII}$ is characteristic for deltaic mouth bar or subaqueous levee deposits (Coleman et al. 1964), and the sequential pattern with a lower wave influenced portion and an upper current dominated portion suggests a prograding mouth bar origin (Elliott 1974). The lower portion of division CII is interpreted as representing distal mouth bar deposition, and the upper portion is interpreted as proximal mouth bar deposits.

$$
\begin{aligned}
& \text { CIII - High sinuosity distributary channel } \\
& \text { deposits }
\end{aligned}
$$

Division CIII in sequence type $\mathrm{C}$ is composed of small-scale fining upward sequences (fig. 11).
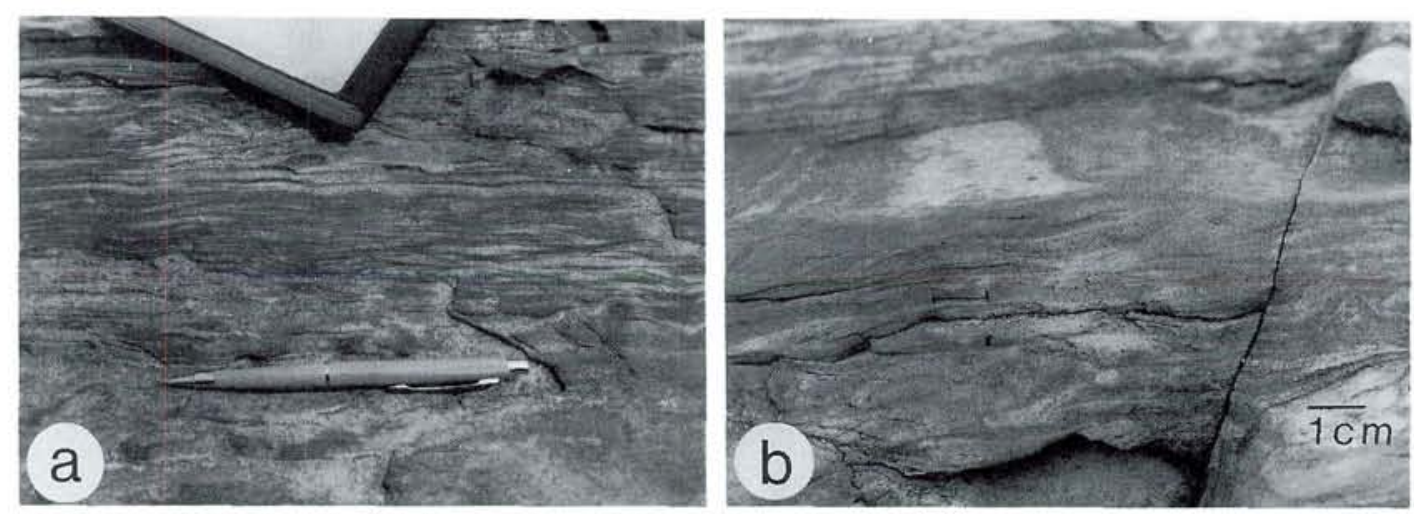

Fig. 12. Characteristic deposits of the lower portion of division CII. $a$ : undulating lamination interpreted as wave-generated. Note local pinching and swelling of individual laminae. Weak cross-lamination dips towards right (SSE). Pencil $13 \mathrm{~cm}$ long. $b:$ small-scale cross-bedding showing unidirectional foreset dip and off-shoots. Interpreted as combined current/wave ripple bedding. Current towards left (NW). 


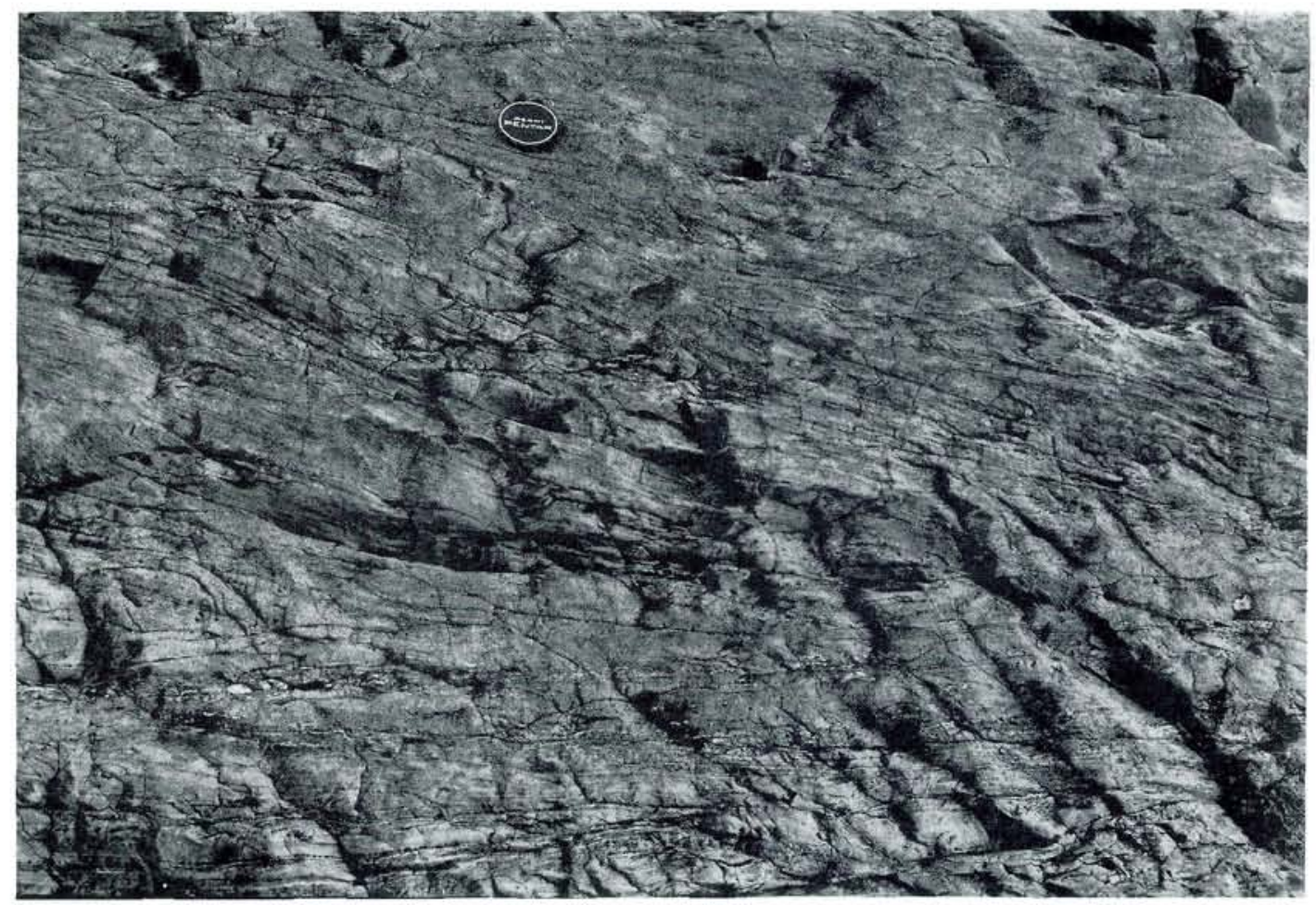

Fig. 13. Sigmoidal cross-set interpreted as epsilon cross-bedding, division CIII. Palaeoflow towards the viewer. Lens cap is $5.4 \mathrm{~cm}$.

The palaeoflow direction differs as much as $143^{\circ}$ from one fining upward sequence to another.

In one of these sequences (the upper one in fig. 11) a solitary sigmoidal large-scale cross-set was observed (fig. 13). The sigmoidal cross-laminae contain internal small-scale cross-bedding, indicating a palaeoflow direction almost at right angles to the dip direction of the sigmoidal laminae. A similar palaeoflow direction was obtained from the trough cross-bedding below the sigmoidal cross-set.

Interpretation: The occurrence of fining upward sequences, the striking difference in flow direction from one sequence to the next and the occurrence of a large-scale sigmoidal cross-set interpreted as an epsilon cross-set (dip direction almost at right angles to the actual flow) indicate a high sinuosity channel origin for this division.

The position of the channel deposits above mouth bar deposits (division CII) suggests that the high sinuosity channels acted as deltaic destributaries.
Summary - sequence type C

Sequence type $\mathrm{C}$ reflects the progradation of a delta system with high sinuosity distributary channels (division CIII) flowing into a lake and resulting in the formation of mouth bars (CII). Mouth bar deposition was dominated by river processes in the proximal part (upper portion of $\mathrm{CII}$ ), whereas wave motion interacted with river currents in the distal mouth bar region (lower portion of $\mathrm{CII}$ ). The distributaries showed transitions to low sinuosity channels in their proximal parts (division CIV). Division CI represents prodelta or overbank deposition.

The example shown in fig. 11 is the most complete section of sequence type $\mathrm{C}$ in the study area. High sinuosity channel deposits are not always present and mouth bar deposits vary greatly in thickness even in laterally equivalent sections. This may be due to erosion by the low sinuosity channels during progradation of the delta systems. An alternative explanation is that the lacustrine area was composed of several local ponds rather than one major lake. 


\section{Environmental reconstruction}

The three types of coarsening upward sequences exhibit a similar trend from fine-grained lacustrine flood basin deposition, represented by the lower division of $\mathrm{CU}$ sequences, to coarser grained low sinuosity channel deposition, represented by the upper division of $\mathrm{CU}$ sequences. The intermediate divisions of the different sequence types, however, reflect different subenvironments leading from the lacustrine environment to the fluvial channel environment.

Despite the differences between the sequence types, they may be combined in a model of gradual establishment of a lateral subsystem of distributaries. Elliott (1974) suggested that a characteristic development of a crevasse subsystem lateral to a newly established distributary channel in a deltaic environment is: I) Minor overbank floods and development of a levee; II) crevasse splay flows as the upward-growing levee is locally breached; III) establishment of permanent crevasse channel - mouth bar couplets as channel aggradation increases the gradient advantage towards the interdistributary bay.

A modification of this model is applied to the present succession of coarsening upward sequences. The major distributary channel in Elliott's (1974) model is replaced by the westward flowing axial river system in the present depositional model. The interdistributary bay is replaced by a flood basin lake. Furthermore the opposite side of the lake is bounded by basin margin fans prograding southwards synchronously with the lateral establishment of the river subsystem (cf. Olsen 1984, 1985). The establishment of the river subsystem occurred in four phases (fig. 14):

Phase I The axial river system has recently been established. A levee is not yet developed. The effectiveness of normal floods is therefore limited. The lake north of the axial river system receives fine grained overbank deposits that form the lower division of coarsening upward sequences (fig. 14a).

Phase II - Channel aggredation and levee construction in the axial river system result in an elevation of the water in the river system above that in the lake, and subsequent floods are enhanced. Crevasse splay flows and sheet splay flows characterize phase II (fig. 14b).
At a position close to the axial river system sheet and crevasse splay deposits accumulate, as seen in sequence type A and B (division AII and BII). At a more distal position the material supplied by splays is deposited as fine-grained density underflow deposits (sequence type $\mathrm{C}$, division $\mathrm{CI}$ ).

Phase III - During further channel aggradation in the axial river system the gradient advantage towards the bay increases. Conditions are suitable for permanent channels. These channels migrate across the splay surface and on reaching the deeper water deposit mouth bars (fig. 14c). Phases III is reflected proximally by low sinuosity channel deposits in sequence types $\mathrm{A}$ and $\mathrm{B}$ (division AIII and BIII). Distally phase III is reflected by mouth bar deposits in sequence type $\mathrm{C}$ (division CII).

Phase IV - During mouth bar - channel progradation the mouth bar deposits are overlain by channel deposits in sequence type $\mathrm{C}$. The lake is finally filled up (fig. 14d). During all four phases the marginal alluvial fans prograde towards south. The result of this is an interbedding and redeposition of alluvial fan sediments in the upper part of $\mathrm{CU}$ sequences (see fig. 2a).

\section{Discussion}

The main drawback to the crevasse subsystem hypothesis is that the presumed Hornelen axial river system was dominated by low sinuosity sandy streams. Such river systems are usually characterized by a poor development of levees. The dominance of sheet splay deposits over crevasse splay deposits in the study area as well as other parts of the flood basin tract suggests that general overbank flow rather than crevassing was the dominating flood mechanism, probably due to the scarcity of vegetation in Devonian time and thus poor levee construction. Because levee construction in deltaic environments is the basis for channel aggradation and thus the creation of a lateral gradient advantage, other driving mechanisms must be sought for the present system. An alternative explanation of the northwards directed low sinuosity streams (upper division of $\mathrm{CU}$ sequences) is that the axial river system prograded towards north due to northward tilting of the basin floor. This would result in a northward 


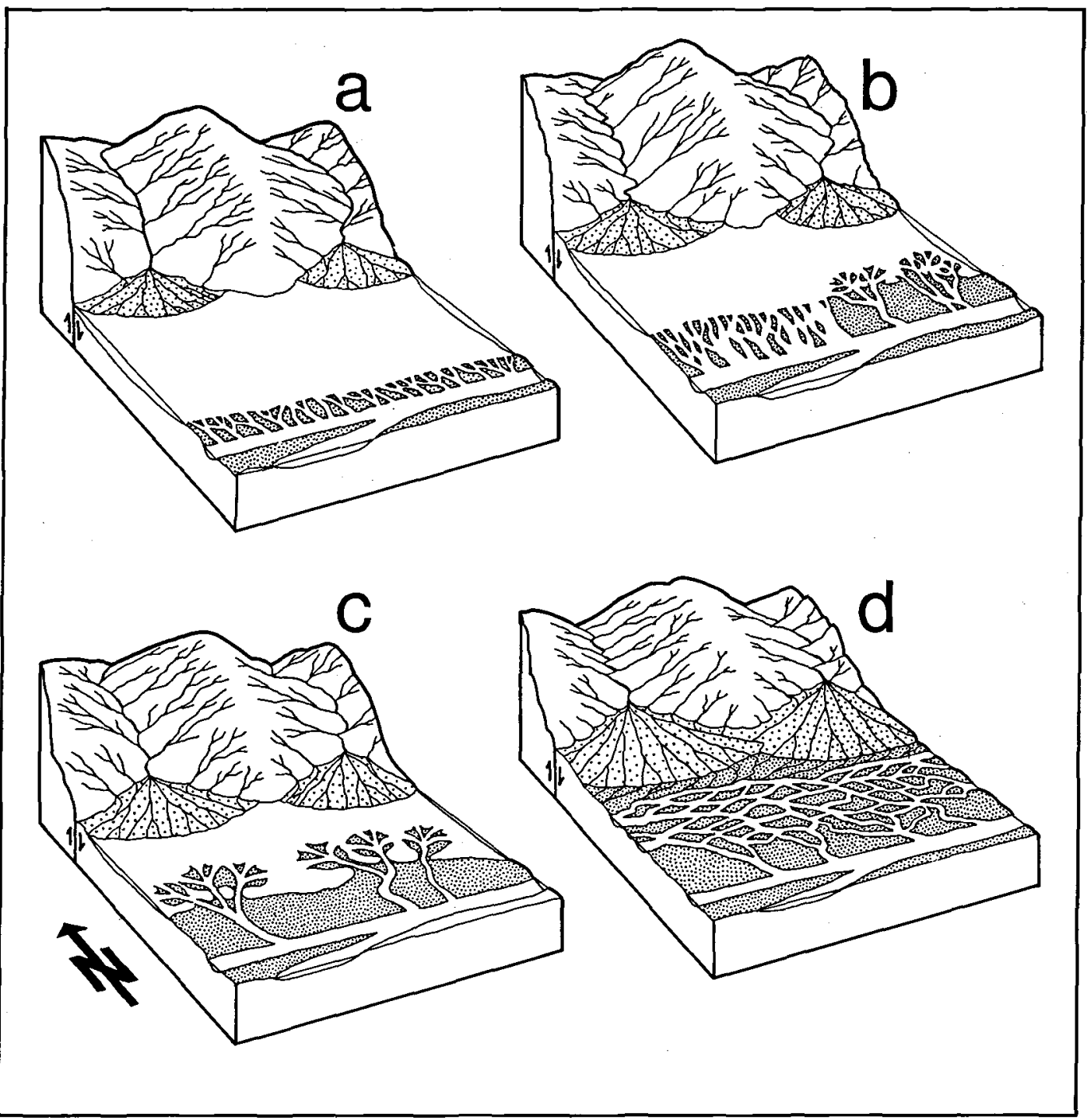

Fig. 14. The four phases in the establishment of a river subsystem. a) phase I, small overbank floods. b) phase II, sheet splay and crevasse splay flows. c) phase III, fluvial channels and associated mouth bars. $d$ ) phase IV complete covering of flood basin by a system of fluvial channels. Usually the flood basin lake is filled during phase II and phase III is therefore seldom developed.

fluvial transport in the whole basin, but Bryhni (1978) has shown that the northward palaeoflow is replaced by a westward palaeoflow south of Storevatnet. The mechanisms should probably be sought in the context of alluvial fan environments. The axial river system is actually comparable to a humid fan. A common feature on alluvial fans is the lateral shift of the depositional area. When one section of the fan has been built up, the streams shift to another, lower section of the fan (Denny 1965). The presence of extensive levees are therefore not necessary for the observed transition from flood basin to active part of the axial river system. The pronounced progradational tendencies of the axial river system (e.g. Steel \& Aasheim 1978) are here suspected to be responsible for the supposed aggradation of the river system in the axial zone above flood basin level. Development of levees, although not extensive, delaid the creation of a subsystem of 
distributaries that turned northward into the flood basin tract and thereby formed the $\mathrm{CU}$ sequences of the present study area.

The term crevasse system has been applied to this type of subsystem (Olsen 1984, 1985). However, this term has the disadvantage of being associated with ephemeral flood flows (crevasse splays) and not associated with more long-lived crevasse channel systems commonly known from deltaic environments. The more informal term river subsystem is accordingly chosen to avoid confusion.

The repetition of coarsening upward sequences in the study area has been shown to be controlled by tectonism (Olsen 1984, 1985) as well as in other parts of the Hornelen Basin (e.g. Steel \& Gloppen 1980). Tectonic subsidence of the basin floor resulted in a sudden rise of the ground water table and thereby creation of lakes on the low-lying flood basin area. This ultimately eliminated the gradient advantage towards the flood basin and the subsystems were abandoned. The longterm response of the tectonic subsidence was, however, a progradation of the axial river system due to the rejuvenation. The response was therefore a reestablishment of lateral river subsystems flowing into the flood basin tract. Steel and Aasheim (1978) showed that the alluvium of the middle to distal reaches of the axial river system was characterized by near-symmetric coarsening-to-fining upward sequences. The creation of that type of seuences instead of $\mathrm{CU}$ sequences as in the more proximal part of the river system could be explained by the creation of lateral subsystems, as those described in the present paper, in the more distal parts of the river system. When an increasing proportion of river flow was drained through the subsystems during the late stages of axial river progradation a graduel abandonment of the axial zone of the river system would occur, resulting in the fining upward top of sequences. River course shifting is thought to have occurred between individual progradations of the axial river system. When the river system lay close to the present study area, the splay-dominated sequence types $\mathrm{A}$ and $\mathrm{B}$ were formed. The lakes were filled up by the splay sediments prior to establishment of perennial channels, because no type A or B sequences could be traced distally into deltaic sequences. In this case the sequence of events comprised only three phases illustrated by figs $14 a, b$ and $c$ (no mouth bar formation). When the course of the axial river system lay farther south, the lakes in the study area had a lateral distal position, and the deltaic sequence type $\mathrm{C}$ was formed.

The axial river system usually had a course relatively close to the study area because sequence types $A$ and $B$ dominate the succession of $\mathrm{CU}$ sequences (fig. 2a).

\section{Acknowledgements}

Lars Clemmensen is thanked for inspiring supervision ans suggestions to improve the manuscript. I am indebted to Poul Henrik Due for dicscussions of sedimentation in the Hornelen Basin. Rewiews by Ron Steel, Brian Rust and Inge Brybni improved the manuscript. René Madsen made the skilful palaeogeographic reconstructions. Pernille Andersen typed the manuscript. Photographic assistance was made by Ole B. Berthelsen and Jacob Lautrup. The English of the manuscript was improved by Chris Pulvertaft.

\section{Dansk sammendrag}

Undersøgelser af sedimentære sekvenser $i$ en marginal del af Hornelen Bassinet (Mellem Devon, Vestnorge) har resulteret $i$ tolkningen af gradvist etablerede fluviale og fluvio-deltaiske subsystemer lateralt tilknyttet et stort flodsystem.

En succession af 8 grovende-op sekvenser (4,5-19 m tykke) er blevet unders $\varnothing \mathrm{gt}$. Tre sekvenstyper er genkendt: sekvenstype A, B og C. Den nedre del af alle sekvenstyper er opbygget af

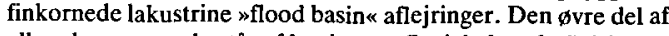
alle sekvenstyper består af lavsinuøse fluviale kanal aflejringer. Den miderste del af de tre grovende-op sekvenser består af sandede "sheet splay" aflejringer (sekvenstype A), »crevasse splay« aflejringer (sekvenstype B) og deltaiske mundingsbarre aflejringer (sekvenstype $\mathrm{C}$ ). Dannelsen af de forskellige typer af grovende-op sekvenser kan forklares ved gentagen lateral etablering af fluviale og fluvio-deltaiske subsystemer i tilknytning til et stort humid alluvialvifte-lignende flodsystem.

Etableringen af subsystemer foregik i fire faser: I) Initiel finkornet levee-overskylning og transport af materiale ud $i$ "flood basin« søer. II) „Sheet splay« strømme og/eller "crevasse splay« strømme. III) Etablering af distributære kanaler og associerede deltaiske mundingsbarrer. IV) Progradering af kanal/mundingsbarre systemer og opfyldning af $»$ flood basin* søer. Ofte blev søerne udfyldt under fase II og den efterfølgende etablering af lavsinuøse kanaler foregik uden dannelse af deltaiske mundingsbarrer.

\section{References}

Bridge, J. S. 1984: Large-scale facies sequences in alluvial overbank environments. Jour. Sed. Petrol. 54, 583-588.

Bryhni, I. 1964a: Migrating basins on the Old Red continent. Nature 202, no. $4930,384-385$. 
Bryhni, I. 1964b: Sediment structures in the Hornelen series. Norsk geol. Tidsskr. 5, 486-488.

Bryhni, I. 1975: The west Norwegian basins of Old Red Sandstone. Proc. IVieme Congress Int. Sed., Nice 1975, 111115.

Bryhni, I. 1978: Flood deposits in the Hornelen Basin, west Norway (Old Red Sandstone). Norsk geol. Tidsskr. 58, 273-300.

Cant, D. J. \& Walker, R. G. 1978: Fluvial processes and facies sequences in the sandy braided south Saskatchewan River, Canada. Sedimentology 25, 625-648.

Coleman, J. M. 1969: Brahmaputra River: channel processes and sedimentation. Sedim. Geol. 3. no. 2/3, 129-239.

Coleman, J. M., Gagliano, S. M. \& Webb, J. E. 1964: Minor sedimentary structures in a prograding distributary. $\mathrm{Ma}$ rine Geol. 1, 240-258.

Collinson, J. D. 1978: Alluvial Sediments. In: H. G. Reading, ed., Sedimentary Environments and Facies, 15-79. Blackwell Scientific Publication, Oxford, London, Edinburgh, Boston, Melbourne.

Denny, C.S. 1965: Alluvial fans in the Death Valley Region California and Nevada. U.S. Geol. Surv. Prof. Pap. 466, $1-62$.

Due, P. H. 1983: Flood basin/shallow lacustrine sediments in Middle Devonian deposits, Hornelen Basin, western Norway. 4th IAS European Regional Meeting. Spilt, Yugoslavia, Abstract Volume, 54-56.

Due, P. H. 1984: A Middle Devonian floodbasin - structures and processes (Hornelen Basin, western Norway). $U n$ publ. cand. scient. thesis, University of Copenhagen, $178 \mathrm{p}$.

Elliott, T. 1974: Interdistributary bay sequences and their genesis. Sedimentology 21, 611-622.

Galloway, W.E. 1981: Depositional architecture of Cenozoic gulf coastal plain fluvial systems. In: F. G. Ethridge, ed., Nonmarine deposits - models for exploration. Soc. Econ. Paleont. Miner., Spec. Publ. 31, 127-155.

Gloppen, T. G. \& Steel, R.J. 1981: The deposits, internal structure and geometry of six alluvial fan - fan-delta bodies (Devonian, Norway) - a study in the significance of bedding sequences in conglomerates. Soc. Econ. Paleont. Miner., Spec. Publ. 31, 49-69.

Harms, J. C. 1975: Stratification produced by migrating bed forms. In: Depositional Sedimentary Structures and Stratification Sequences. Soc. Econ. Paleont. Miner. Short Course no. 2, Dallas, 45-62.

Harms, J. C. \& Fahnestock, R. K. 1965: Stratification, bedforms, and flow phenomena (with an example from the Rio Grande). Soc. Econ. Paleont. Miner., Spec. Publ. 12, 84-115.

Harms, J. C., Southard, J. D. \& Walker, R. G. 1982: Structures and sequences in clastic rocks. SEPM short course no. 9 Soc. Econ. Paleont. Miner., Calgary 2-1, 3.51.

Lambert, A. \& Hsü, K. J. 1979: Non-annual cycles of varve- like sedimentation in Walensee, Switzerland. Sedimentology $26,453-461$.

Larsen, V. \& Steel, R. J. 1978: The sedimentary history of a debris flow-dominated alluvial fan - a study of textural inversion. Sedimentology 25, 37-59.

Miall, A.D. 1977: A review of the braided-river depositional environment. Earth-Science Reviews, 13, 1-62.

Middelton, G. V. \& Hampton, M. A. 1976: Subaqueous sediment transport and deposition by sediment gravity flows. In: D. J. Stanley \& D. J.P. Swift, eds, Marine sediment transport and environmental management, 197-218. WileyIntersci. Publ. New York.

Olsen , H. 1983: Lacustrine delta sequences in Middle Devonian deposits western Norway. 4 th IAS European Regional Meeting, Split, Yugoslavia, Abstract Volume, 127-129.

Olsen, H.1984: Composite coarsening upwards sequences - an interacting alluvial fan and major crevasse system, reflecting tectonism (M. Devonian, Hornelen Basin, Norway). Unpubl. cand. scient. thesis, University of Copenhagen, $196 \mathrm{p}$.

Olsen, H. 1985: Synchronous progradation of two independent alluvial systems - an example of tectonic control on sedimentation - Hornelen Basin, M. Devonian, Norway. 6th European Regional Meeting, Lleida, Spain. Abstract Volume, 337-340.

Pollard, J. E., Steel, R. J. \& Undersrud, E. 1982: Facies sequences and trace fossils in lacustrine/fan delta deposits, Hornelen Basin (M. Devonian), western Norway. Sediment. Geol. 32, 63-87.

Raaf, J. F. M. de, Boersma, J.R. \& Gelder, A. van 1977: Wave-generated structures and sequences from a shallow marine succession, Lower Carboniferous, Country Cork, Ireland. Sedimentology 24, 451-483.

Reineck, H-E. \& Singh, I. B. 1980: Depositional sedimentary Environments. With Reference to Terrigenous Clastics, $p$. 549. Springer-Verlag. Berlin, Heidelberg, New York.

Steel, R. J. 1976: Devonian basins of western Norway; sedimentary response to tectonism and to varying tectonic context. Tectonophysics 36, 207-224.

Steel, R. J. \& Aasheim, S. 1978: Alluvial sand deposition in a rapidly subsiding basin (Devonian, Norway). In: A. D. Miall, ed., Fluvial sedimentology. Mem. Can. Soc. Petrol. Geol. 5, 385-413.

Steel, R. J. \& Gloppen, T. G. 1980: Late Caledonian (Devonian) basin formations western Norway - signs of strikeslip tectonics during infilling. In: H. Reading \& P. F. Ballance, eds, Sedimentation in oblique-slip mobile zones. Spec. Publ. Int. Ass. Sediment., 4, 79-103.

Steel, R. J., Mahle, S., Nielsen, H., Røe, S. L. \& Spinnangr, A. 1977: Coarsening-upwards cycles in the alluvium of Hornelen Basin (Devonian), Norway: Sedimentary response to tectonic events. Bull. geol. Soc. Am. 88, 1124 1134. 